\title{
Militares e bolsonarismo: um caso da transição falhada e democracia inacabada
}

\author{
Karl Schurster \\ karl.schurster@gmail.com \\ Universidade de Pernambuco (Brasil) \\ Francisco Carlos Teixeira Da Silva chicotempo@uol.com.br \\ Universidade Federal de Juiz de Fora (Brasil)
}

Recibido: 01/06/2021

Aceptado: 08/07/2021

Publicado: $15 / 07 / 2021$

Resumo: Este texto procura analisar o conceito de transição falhada e democracia inacabada no passado recente do Brasil. As formas de como a percebemos a "abertura política", ou "transição democrática" brasileira e como essas análises construíram um "senso comum" de que o processo foi um "pacto" entre o então regime militar e os representantes da oposição construindo a tese da "conciliação" que não abarca os outros e complexos elementos envolvidos no processo de transição, são nosso foco. Defenderemos a ideia de que o risco a democracia no Brasil vem da simbiose entre os setores mais duros das Forças Armadas, com adesão de parcela significativa da sociedade construindo uma linguagem e ação política brutal, fruto da nossa democracia inacabada.

Palavras-chave: Militares, Bolsonaro, Democracia, Transição.

* Cómo citar este artículo: Schurster, K. y Teixeira Da Silva, F. C. (2021). Militares e bolsonarismo: um caso da transição falhada e democracia inacabada. Relaciones Internacionales, 30(60), 130. https://doi.org/10.24215/23142766e130

Editor: Juan Alberto Rial, Instituto de Relaciones Internacionales Facultad de Ciencias Jurídicas y Sociales (Universidad Nacional de La Plata)
Entidad editora: Relaciones

Internacionales, es una publicación del Instituto de Relaciones Internacionales (Facultad de Ciencias Jurídicas y Sociales (Universidad Nacional de La Plata Argentina)
Vol 30 -

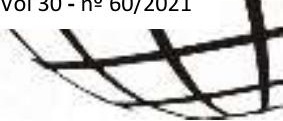




\section{Military and Bolsonarism: a case of failed transition and un- finished democracy}

\section{Karl Schurster ${ }^{1}$, Francisco Carlos Teixeira Da Silva²}

Abstract: This paper seeks to analyze the concept of failed transition and unfinished democracy in Brazil's recent past. Our focus here includes the different ways in which we perceive Brazilian "political opening" or "democratic transition" and how these analyses constructed a "common sense" that the process was a "pact" between the then military regime and representatives of the opposition, constructing the thesis of "conciliation" that does not embrace the other complex elements involved in the transition process. We will support the idea that the risk posed to democracy in Brazil comes from the symbiosis between the most hardened sectors of the Armed Forces, with the adhesion of a significant portion of society, building a brutal political language and action, fruit of our unfinished democracy.

Keywords: Military, Bolsonaro, Democracy, Transition.

\footnotetext{
${ }^{1}$ Pós-Doutor em História pela Universidade Livre de Berlim. Doutor em História Comparada pela UFRJ com estágio na Universidade Livre de Berlim. Investigador Visitante na Universidade do Porto. Professor Livre Docente em História da Universidade de Pernambuco.

${ }^{2}$ Pós-Doutor em História pela Universidade de Berlim e pela Universidade Técnica de Berlim. Doutor em História pela Universidade Federal Fluminense. Professor Titular de História Moderna e Contemporânea da UFRJ e professor emérito da Escola de Comando e Estado-Maior do Exército. Atualmente é professor na Universidade Federal de Juiz de Fora.
} 


\section{Militares y Bolsonarismo: un caso de transición fallida y de- mocracia inacabada}

\section{Karl Schurster, Francisco Carlos Teixeira Da Silva}

Resumen: Este trabajo pretende analizar el concepto de transición fallida y democracia inacabada en el pasado reciente de Brasil. Nuestra atención se centra en las formas de percibir la "apertura política" o la "transición democrática" brasileña y cómo estos análisis construyeron un "sentido común" de que el proceso fue un "pacto" entre el entonces régimen militar y los representantes de la oposición, a partir de la construcción de la tesis de la "conciliación" que no abarca los demás elementos complejos involucrados en el proceso de transición. Defenderemos la idea de que el riesgo para la democracia en Brasil proviene de la simbiosis entre los sectores más duros de las Fuerzas Armadas, con la adhesión de una parte significativa de la sociedad que construye un lenguaje y una acción política brutal, fruto de nuestra democracia inacabada.

Palabras clave: Militar, Bolsonaro, Democracia, Transición. 


\section{Introdução}

"Nós perdemos a guerra". Essas foram as primeiras palavras de Horst Möller (2012), parafraseando o comissário do povo Friedrich Ebert, na abertura da Assembleia Nacional em fevereiro de 1919. Em verdade, o povo alemão não estava efetivamente preparado para admitir o fato: a derrota. Há um paralelo possível entre esse sentimento do passado recente alemão com a história do presente brasileiro. As eleições de 2018, no Brasil, marcariam aquilo que o Imperador Guilherme II afirmou em 1914: "Não reconheço mais partidos, só reconheço alemães!" (Möller, s.d). O retorno a um tipo de nacionalismo que alguns intitulam de "populismo de direita" em conjunto com as práticas de deslegitimação das instituições do mainstream esvaziando a arena do político pela exacerbação de uma retórica fascistizante marcariam os primeiros anos do governo Jair Bolsonaro. Nos últimos dois anos o governo se ocupou, quase que exclusivamente, a combater as causas que "supostamente ameaçariam a sua existência". Nesse caso, o passado imaginado, do que foi o governo "comunista do Partido dos Trabalhadores". Com isso, tornou-se cada vez mais evidente a necessidade de discussão sobre como manter a democracia sob condições tão desfavoráveis. Essa discussão, apresentada por Gandhi (2008), Levitsky \& Way (2010) e Costa Pinto (2021), demonstram como os novos regimes autoritários se vestem de democracias, mas em verdade devem ser definidos como "regimes híbridos" ou "autoritarismos competitivos". Por mais que possuam várias características do agir político democrático, como eleições, a existência de múltiplos partidos ou mesmo não implementação de uma censura rígida, constroem novas formas de repressão a cidadania e de controle da sociedade civil. Primeiro pela linguagem autorizadora, depois pela ação catártica, quase sempre violenta.

Ocorreu em grande parcela da população brasileira a esperança de que a eleição de Bolsonaro instaurasse um "novo modelo político", fora dos jogos e acordos do sistema, e com isso os problemas da sociedade seriam resolvidos de forma rápida e efetiva. O que não foi entendido, nem pelas elites políticas e sociais, tampouco por grande parcela da população massivamente pobre no Brasil é que Bolsonaro jamais esteve em condições de proporcionar aquilo que se esperava dele. Por isso, as promessas radicais de uma "revolução conservadora" tentando desfazer o sistema "por dentro" foi uma retórica muito mais pretenciosa e ilusória do que realista. O que esse texto pretende abordar, num sentido específico, é como um processo de transição falhada, de uma sociedade em processo de transformação, constituiu uma "democracia inacabada" e com isso abriu margem para o surgimento e manutenção de figuras políticas como Bolsonaro e, também, a permanência de grupos militares dentro da arena política.

A eleição de Jair Bolsonaro para a presidência da República em 2018 - malgrado uma série de elementos questionáveis - desde um amontoado de fakenews até a inelegibilidade do ex-presidente Lula da Silva - a bordo de 57.797.847 de votos interrompia uma sucessão de eleições presidenciais em que a Centro-Esquerda elegia seus candidatos (Vargas, Juscelino, Jânio Quadros, Jango - um hiato com a Ditadura Civil-Militar entre 1964-1985 e novamente com FHC, Lula e Dilma). Não só a chapa Bolsonaro-Mourão, este um general da reserva conhecido por declarações antirrepublicanas, mostravam-se fora do "arco constitucional" da Nova República, como ainda abertamente elogiavam a Ditadura CivilMilitar e prometiam um governo formado por militares. Os principais e mais graves mo- 
mentos do regime autoritário eram negados - supressão das liberdades, sequestros, torturas - ou mesmo considerados "necessários", em virtude do momento de "guerra" que o país passava.

Tal retorno ao passado, ensejou, por sua vez, um forte movimento de retorno ao tema por parte de pesquisadores. Historiadores, cientistas sociais, politólogos e, mesmo jornalistas, começaram um intenso processo de "revisão" dos anos de 1964-1985 como forma de resposta a "idealização", por parte da Ultradireita, da ditadura no Brasil. Muito especialmente, a imposição do Ato Institucional Número 5, o conhecido "Al-5", e suas terríveis consequenciais, começaram um novo ciclo de debates e estudos.

No entanto, um período, e temática, ficaram menos evidente neste debate: a forma assumida pela transição democrática brasileira. Denominada de "Abertura" (do regime militar") e dirigida desde cima, pelos próprios militares, e que aos poucos toma fôlego e se espraia para as ruas com massivos movimentos populares como os movimentos pela "Anistia Geral" (1975-1979) e o movimento pelas "Diretas Já" (1983-1984), empurram o regime para o seu final. Embora os "bolsões" de resistência extremistas, no interior do próprio regime, continuassem a reagir contra a "Abertura". O Projeto de Abertura Política nunca foi aceito, unanimemente, pelos militares, ensejando uma brutal luta política nos quartéis e em seus porões.

Essa reação incluiu o Golpe de Estado falhado de 1977 de Silvio Frota, que tinha como ajudante de Gabinete o então capitão Augusto Heleno, atual general ministro-chefe do GSI do Governo Bolsonaro. O projeto formulado por Geisel-Golbery, mesmo sendo autoritário e limitado, era considerado por setores "linha dura" por demais favorável aos "comunistas". Para combatê-lo, patrocinou-se uma onda de Terrorismo de Estado por todo o país, em especial entre janeiro e agosto de 1980, tendo como alvos o governador Leonel Brizola, a convenção do PMDB, bancas de jornais em vários estados (para coibir a venda de jornais de Oposição). São atingidas, com vítimas, inclusive letais, as sedes dos jornais "Em Tempo", "Hora do Povo", "Tribuna Operária" e "Tribuna da Imprensa", a "Casa do Jornalista", em Belo Horizonte, o Teatro Tuca, em São Paulo, no Colégio Social (ferindo cerca de dez estudantes), em Salvador, a Ordem dos Advogados do Brasil/OAB, o Riocentro, onde se realiza um espetáculo de música popular e a Câmara dos Vereadores. Tais práticas terroristas, com funcionários civis e militares agindo como terroristas, jamais foram apuradas ou punidas.

A análise, bastante comum, que a transição democrática brasileira foi um "pacto" entre o regime militar e os representantes moderados da oposição - o que é uma explicação recorrente na história do Brasil sobre as "conciliações" - não abarca, entretanto, os elementos de violência e de participação popular envolvidos no processo de transição. Daí a importância de "revisar" tais processos e projetar, à luz da fragilidade atual da Nova República, implantada com a Constituição de 1988, o sentido e forma da transição e o papel dos militares nesse processo.

\section{Transições}

A "questão" das transições democráticas na América Latina foi tratada por inúmeros 
historiadores, cientistas políticos e sociólogos, gerando uma vasta literatura especializada. O caso do Brasil, a chamada "Abertura" política, foi um processo especial dirigido diretamente pelo grupo no poder, os militares (o Projeto Geisel-Golbery), e marcado por sua longuíssima duração - 1979-1988 -, gerando fortes problemas teóricos e metodológicos, além das consequências políticas duradouras, recolocadas hoje na Nova República. Desde logo alguns especialistas sobre o tema devem ser destacados: Guillermo O’Donnell (1991) ao propor, em comparação com outros países latino-americanos, um modelo clássico de "transições", que terá forte impacto em estudos posteriores. Suas análises viriam desafiar o diagnóstico "fatalista" de Samuel Huntington - dentre os quais The Modest Meaning of Democracy-, onde "ondas" de autoritarismo sucessivas se alternariam, na América Latina, com "aberturas" democráticas, num continente não "vocacionado" à democracia (Huntington, 1989). Em tal debate, sobre a difícil "vocação" democrática latino-americana, o autor lança sua tese sobre as "ondas" de democracia e autoritarismo na América Latina, onde a temática iguala-se em "fatalismo" a outros temas como a eliminação da corrupção, da pobreza ou a injustiça social, constituindo-se em mais uma das diversas teses da vulnerabilidade inerente dos latino-americanos em face da diversa "vocação" dos povos anglosaxões ao desenvolvimento pleno. Muitas vezes relacionada com a "herança histórica" do "iberismo", e com a existência, então, das longas ditaduras franquistas e salazaristas, tais teses mostram-se fatalistas, deterministas e historicistas, não levando em conta os desenvolvimentos recentes e a história específica de cada povo. Correndo por fora do "modelismo" dominante nas ciências políticas, Denkwart Rüstow (1970: pp. 337-363) - em Transitions to democracy: Toward a dynamic model, de 1970, procura trazer o conflito social para dentro do debate e, muito especialmente, o papel das elites políticas e sua vocação, ou a ausência de vocação e interesse, para com a democracia.

O livro de Alfred Stepan (1975) - The Military in Politics - de 1971, publicado no Brasil em 1975, em pleno Regime Militar, trouxe uma verdadeira renovação nos estudos militares no Brasil. Não se trata, no entanto, de um "inovador' como muitos querem, em desconhecimento da literatura histórica já existente no Brasil. O historiador brasileiro Carlos Fico esclareceu, recentemente, a trajetória do trabalho de Stepan. As relações civismilitares, no Brasil, já haviam sido estabelecidas como campo de estudo pelo ensaio seminal $O$ que foi o Tenentismo?, de Virgílio Santa Rosa (1963), publicado em 1963, em plena ebulição política, no exato momento em que se discutia o papel dos militares nos destinos da Nação. O próprio ensaio constituía-se em uma atualização de uma obra maior do mesmo autor, de 1933, escrito no imediato pós-Revolução de 1930, denominada "O Sentido do Tenentismo" (Rosa, 1976), onde o fenômeno das revoltas militares dos anos de 1920 desembocava no "primeiro movimento saneador" e revolucionário da República. A obra de Santa Rosa incluía, no entanto, a defesa da Reforma Agrária e o combate ao latifúndio como temáticas de época, radicalizando e fastando-se da experiencia getulista. Tal trabalho, deve ser incluído no grande conjunto renovador - a grande da vaga do chamado "Redescobrimento do Brasil" com Gilberto Freyre, Sérgio Buarque de Holanda, Nelson Werneck Sodré e outros - que indagava a natureza e significado das instituições brasileiras e o que fazia o Brasil ser diferente e original, em suma, ser "brasileiro".

A obra de Santa Rosa terá forte impacto nos estudiosos brasileiros, em especial na "Escola Sociológica da USP", com Florestan Fernandes, Fernando Henrique Cardoso, Boris 
Fausto e Francisco Weffort. Os estudiosos brasileiros, depois de 1964, apesar das dificuldades impostas pela censura política, acompanharam com afinco o debate, em especial em núcleos com o CEBRAB, pioneiro nos estudos sobre a modernização brasileira e em cursos da Universidade Federal Fluminense. Francisco Weffort (1990) foi um estudioso constante no campo, responsável por um amplo seminário, na USP, sobre o tema da "Transição" no Brasil. Já Lucília de Almeida Neves e Vera Cardoso (1985), publicaram uma detalhada análise sobre a trajetória de Tancredo Neves, onde lançavam luzes sobre todo o processo de "Abertura" política no Brasil em 1985.

Uma nova geração de pesquisadores, aprofundou o debate sobre o tema "Militares", "Regime Militar" e "Transição", com destaque para Carlos Fico, Daniel Aarão Reis Filho e João Roberto Martins Filho, que conseguiram aportar contribuições significativas, incluindo a questão da periodização do regime militar e a análise dos diversos grupos no interior das FFAA, como veremos em seguida. Coube a Anthony Pereira uma singular contribuição ao analisar o papel da Constituição e dos constituintes de 1988 na configuração da Nova República, por ele significativamente denominada de "democracia feia" - um debate que enfrentaremos. Desde logo, na contramão da euforia, com o fim do Regime Militar, que Aarão Reis sublinhou o caráter "civil-militar", destacando a presença de amplos segmentos empresariais e das classes medias no regime de 1964.

\section{Nova República: a democracia feia}

Anthony Pereira, por sua vez, destacou na transição e na nova democracia depois de 1988, a ambiguidade e a insuficiência das garantias dos Direitos Civis. A ausência de uma real reforma das instituições republicanas, e em especial das polícias e da Justiça, que teria deixado o cidadão brasileiro - em especial o pobre, mestiço, preto, a mulher - cada vez mais distante dos mesmos Direitos Civis proclamados pela própria Constituição de 1988. Esta, cada vez mais emergia como um documento declaratório. Por outro lado, a maciça presença de constituintes liberais-conservadores - 500 contra 59, eleitos em 1986 e responsáveis pela Constituição de 1988 - abrira caminho para a inserção de institutos que somente nos anos seguintes mostrar-se-iam plenamente em suas consequências, entre eles o hoje famoso Artigo 142. Seriam artigos de garantias de autonomia e poder aos militares, que se retirariam do poder muito distantes de uma derrota, como no caso da Argentina, Portugal ou Grécia. Citava-se, na ocasião, claramente, os "Pactos de Moncloa" e uma longa e ordenada retirada do poder, como no caso do franquismo espanhol ou dos militares no Chile (SANTOS, 2017). Na verdade, os militares, na Nova República, guardariam, via o Artigo 142, um largo poder de intervenção na vida pública. No governo Bolsonaro tal artigo seria frequentemente citado como a esdrúxula fórmula de "Intervenção Militar Constitucional". Daí, na contramão de Ulisses Guimarães, que denominou a Constituição de "cidadã', Pereira denomina a democracia da Nova República de "feia".

A persistência do patrimonialismo - marca das oligarquias que se manteve nas ditaduras modernizantes militares, em aliança às custas das populações rurais e camponesas e via manutenção da estrutura agrária oligárquica - e a negação do acesso popular aos serviços e bens públicos foi, por sua vez, o destaque de Adam Prezeworski (1985) para o conceito de "democracia de baixa intensidade". As transições democráticas não souberam 
superar tais estruturas, herança histórica latino-americana, muitas vezes tratadas como natureza do "iberismo colonial", mesmo quando lá se vão duzentos anos de independência nacional. Assim, devemos considerar, ao largo de qualquer fatalismo histórico, a persistência do patrimonialismo no âmbito de alianças e conciliações políticos como parte fundamental da análise do colapso/descrédito/corrosão/decepção das democracias no continente. Duas vias abrem-se para esse processo de "falhamento" histórico das democracias sucessoras:

1. No caso das ditaduras militares, registrada a diversidade dos grupos militares (Martins Filho, 1995), e seus laços com a sociedade civil, como destacou originalmente Santa Rosa;

2. Há um "núcleo duro" com um projeto de poder que vinha amadurecendo desde o início dos anos de 1950. A presença e ação de tal grupo explicita a sucessão de pronunciamentos, manifestos e tentativas de putsch desde a primeira derrota da UDN para o varguismo até 1977.

A imposição por Geisel do seu projeto de "Abertura" - que acaba sendo derrotado, por sua vez, "nas ruas", sendo ampliado do ponto de vista das liberdades e das conquistas sociais pela Constituição de 1988, gera, por sua vez, um poderoso grupo de recalcitrante no interior das Forças Armadas. Conseguiram impor aos constituintes o Artigo 142, e outros dispositivos e, no entanto, nunca consideraram a Nova República como a forma definitiva de Estado no Brasil.

Alijados do poder com a derrota do, então, ministro-general Silvio Frota, em 1977, formaram um grupo coeso, reacionário, embedeb nas instituições republicanas - FFAA, polícias, escolas e academias militares na contramão da tradição "castelista" e civilista existente nas FFAA - que se lançará sistematicamente na conquista do Estado e fará uma aliança histórica com o empuxo fascista vindo de baixo, do conjunto da sociedade. Moldados por uma constante de cursos de MBAs, ministrados por fundações privadas contratadas pelo DeCEX - Departamento de Cultura e Educação do Exército - com uma formação ultraliberal e crítica a qualquer papel do Estado na economia, desenvolveriam uma visão privatista, anti-desenvolvimentidsta e antinacionalista no uso dos recursos naturais do país. Verão nos partidos desenvolvimentistas, e em especial no PT, uma terrível ameaça "bolivariana", contra a qual devem estar permanentemente mobilizados. Em vários pontos, em especial no programa econômico, "moderados" e "duros" se encontram.

\section{Entre Moderados e "Duros"}

O que diferencia "duros" e "moderados" não é a tática - por exemplo, o recurso à tortura, a censura, ou a supressão dos Direitos Civis e, sim, seus projetos de longo prazo para a República. Tais setores "duros" no interior das FFAA jamais aceitaram a "Abertura" como proposta no Projeto Golbery-Geisel, e sempre reagiram com dureza ao setor castelistas (Idem). Conspiraram em 1977, no “quase-golpe' contra Geisel, voltaram a conspirar em 1979 - contra a sucessão via João Figueiredo e contra o Decreto da Anistia, de 1979, considerado "brando" com os "subversivos" e reagiram de novo violentamente nos anos de 1980 e 1981 com o Terrorismo, explodindo dezenas de bombas por todo o país, inclusi- 
ve nos episódios da OAB, da Câmara dos Vereadores do Rio de Janeiro e do Rio Centro, conforme detalhado por Elio Gaspari (2003). No “núcleo duro", desde 1964, já havia, in potentia, fortes elementos fascistas. O convívio complexo, mais forte no Governo Médici (1969-1974) de militares reacionários com elementos fascistas oriundos da sociedade civil e, então, em declínio até seu expurgo em 1977, não representou, no entanto, sua eliminação.

Da mesma forma, o reacionarismo da sociedade brasileira, seu egoísmo social, já convivia, com elementos fascistas, desde os anos de 1920, expressos no Integralismo e, hoje, no Neointegralismo e nas suas expressões religiosas (Dotta, 2012). A modernização autoritária e a crise econômica, com a ascensão de novos grupos sociais, potencializaram a possibilidade fascista. O encontro, depois de 2013 , se fez irresistível, e se materializou nas faixas e cartazes como "Intervenção Militar Já".

Alguns regimes, de longa duração, como a ditadura de Franco na Espanha, oscilaram no tempo e na sua forma, conforme o equilíbrio interno de forças e as conjunturas internacionais, entre uma ditadura militar, um regime fascista e uma modalidade própria de fascismo clerical - Fábio Py (2020) chamará de "cristofascismo" e Ernst Nolte (1963) de "clericofascismo". Neste sentido, não caberia estabelecer condições do tipo aut alterum, uma análise eliminando a outra, mas da conjugação no tempo e nas condições específicas das diversas formas/fases de ditadura e fascismo - em movimento constante.

A "Transição" brasileira foi, de forma clássica, caracterizada como negociada com as forças herdeiras da ditadura. Dada uma certa contemporaneidade, o "Caso Espanhol" de Transición, como descrito por Juliá Santos, foi exemplar. Na Espanha, hoje sabemos, as negociações deram-se diretamente entre Felipe Gonzalez, em 1976, do PSOE/Partido Socialista Operário Espanhol e o "Servicio Central de Documentación" (Seced), o serviço secreto criado ainda na época de Francisco Franco, em 1972, para o controle político do país durante o "tardofranquismo", os dois atores centrais da transição espanhola ${ }^{3}$. Então se estabeleceram os "limites" supostos ou aceitáveis da transição democrática. Para o grande público, os chamados "Pactos de la Moncloa", de 1977, reunindo Adolfo Suarez (UCD), Felipe Gonzalez (PSOE) Santiago Carrillo (PCE), e demais líderes, seriam a face visível, e aberta, de negociações ocultas entre apenas dois atores básicos. O paralelo foi seguido no Brasil, em especial após a morte de Tancredo Neves, quando o general Ivan de Souza Mendes (1922-2010), chefe do SNI/Serviço Nacional de Informações entre 1985 e 1990, desenvolveu todos os esforços possíveis para evitar a extinção do órgão, que ele chefiava, pelo presidente Collor e foi o responsável pelo sumiço da documentação até então produzida; o general Leônidas Pires Gonçalves (1921-2015), Ministro do Exército indicado por Tancredo Neves e mantido no Governo Sarney; e o General Otávio Medeiros (1922-2005), um íntimo do presidente João Figueiredo, então Comandante da Amazônia e chefe do SNI entre 1978 e 1985, quando se deu o atentado ao Riocentro e outros contra movimentos e personalidades da Oposição - os anos fundamentais da "Abertura" política

3 El País. El día que 'Isidoro' sedujo a los espías de Suárez, 22/09/2029. In:

https://elpais.com/politica/2019/09/19/actualidad/1568907106 294742.html, consultado em 20/04/2021. 
no Brasil - tornam-se os fiadores do frágil Governo de José Sarney, na condução dos momentos mais tensos da Transição. Note-se bem, todos atos de se deram após a publicação da Anistia de 1979 e, portanto, não estavam cobertos por sua jurisdição.

Esses três militares foram os homens que moldaram a "Abertura" política desde 1978 no Brasil, estabeleceram limites, ritmo e as condições, incluindo o "golpe" da posse de Sarney no impedimento de Tancredo Neves - tornando-se o General Leônidas Pires Gonçalves, nas palavras do próprio Tancredo Neves, o "jurista do Sarney".

No caso do Brasil e Chile coube aos próprios membros do Regime Militar no Poder Geisel/Figueredo e Augusto Pinochet - estabelecer os limites e ritmo da abertura do regime. A dinâmica social e política, a intensidade da organização da sociedade civil, tiveram, no entanto, importante papel em contra-arrestar tais "limites" e alterar o "ritmo" impostos pelas forças da conservação. Em especial os movimentos populares nas ruas, as greves e a mobilização sindical ampliaram a "Abertura" para além dos seus estreitos limites iniciais. Mas, em seu conjunto - como comprovam, no Brasil, o Decreto da Anistia de 1979 e a derrota do Movimento "Diretas Já" - deu-se a "captura" das transições pelos objetivos dos setores conservadores das FFAA em ambos os países. A eleição, indireta e por um colégio eleitoral nos moldes da ditadura, de Tancredo Neves e de José Sarney, em 1985, e a tragédia subsequente - a morte do presidente eleito -, artes do destino, levando um antigo líder da ditadura e seus conselheiros militares a dirigir a Transição/Abertura, sublinhariam os seus limites. Somar-se-ia a isso um Congresso Nacional, também constituinte (1987/88), onde a oposição teria cerca de 10\% de assentos (o governo contava com 509 votos contra 50 da oposição). Essa nova realidade política - uma maioria conservadora no Congresso Nacional - imporia sua vontade: o "Centrão" - uma aglomeração suprapartidária majoritária de "Centro" até a Extrema-Direita. Ao mesmo tempo, no cenário internacional, o "Socialismo realmente existente" ruía: desde 1979/1980 o "Sindicato Autônomo Solidariedade", na Polônia desafiava o regime comunista e abria graves brechas nos países comunistas; a "gerontocracia" soviética decaia com rapidez; Hungria e Tchecoslováquia faziam reformas liberalizantes e a oposição na República Democrática Alemã era cada vez mais forte, culminando em 1989 com a derrubada do odioso "Muro" em Berlim. Em 1991, tudo vinha a baixo. O "Monolito" desabava. Em tais condições a oposição de Esquerda no Brasil estava profundamente despreparada para a "Abertura" e um projeto social para o país, sem um discurso alternativo para apresentar como alternativa a uma ofensiva neoliberal.

O debate clássico na literatura aponta que tais "Transições tuteladas" desembocam, em geral, em "Regimes Tutelados", normalmente com garantias formais de Direitos de "primeiro grau" - como garantidas na Constituição de 1988 - voto, reunião e expressão mas, jamais aos direitos amplos e includentes de participação real do "demos" ao acesso aos serviços e aos bens sociais, perpetuando a situação de desigualdade e de injustiça social. Da mesma forma, a paralisia da "democratização" frente as instituições como as polícias e a Justiça, marcadas pela violência massiva, em especial contra jovens negros e pardos, mulheres e minorias, característica dos velhos regimes ditatoriais e oligárquicos, redundaria na brutal sequência de massacres contra grupos sociais subalternos (Alves, 2020). Garantia-se, assim, a reprodução, perpetuação, da "democracia feia", como sublin- 
ha Anthony Pereira. Tal contradição entre a afirmação "declaratória" entre "direitos gerais" e as garantias reais, fundamentais, para exercê-los, os efeitos da Transição pactuada incidiriam em várias instituições da República, e seu habitus, redundando na banalização da violência que se institucionalizaria, em especial nas polícias militares e suas congêneres, tais como a polícia civil, as guardas penitenciárias, corpo de bombeiros, guardas de vigilância um processo rápido de milicização de instituições do Estado (Paes Manso, 2018).

A democratização advinda com a "Abertura" não seria acompanhada pela diminuição, sequer pela mitigação, da violência contra os grupos sociais subalternos rurais ou das periferias urbanas das grandes cidades ${ }^{4}$.

\section{Transições e seus modelos: a inovação brasileira.}

O debate acima esboçado sobre mudança e padrão de Transição possui um denso corpus teórico estabelecendo o campo dos estudos da "Transitologia". Coube a Dankwart A. Rüstow (1924-1996) dedicar-se a compreensão dos regimes autoritários, sua crise e transição à democracia de forma sistemática. O otimismo de Rüstow acerca de uma Habituation dos diversos grupos políticos, incluindo as elites/corporações antes detentoras do poder e, fundamental, do crescente declínio do autoritarismo na América Latina, infelizmente - aliás como previsto por Prezeworski - não ocorreu. Não só as elites do poder não se "habituaram" com o novo jogo democrático, como ainda se se tornaram nostálgicas de uma falsa "idade do ouro", idealizada, das ditaduras. O elogio ao passado e sua idealização como um "tempo perdido" torna-se um reforço, comum, nos processos de fascistização. Nas crises institucionais, tais utopias regressivas, são oferecidas como alternativas, num processo de aproximações sucessivas e de radicalização acumulativa, no qual o Negacionismo Histórico desempenha um papel central na novilingua apresentada pelos fascistas.

Os bolsões de "radicais" no interior das Forças Armadas desempenharam, neste processo, um papel central. Forneceram uma constante fonte de "memórias imaginadas" sobre os tempos da Ditadura em comparação da corrupção e do "descalabro, por vezes da ausência de patriotismo, da Nova República. Em várias oportunidades desafiaram, com sucesso, o Poder Civil, como no "Caso Viegas", em 2004, levando a demissão do Ministro da Defesa e constrangendo o governo nos casos referentes as narrativas sobre os desaparecidos e os torturados. O enfrentamento com a Comissão Nacional da Verdade/CNV, no governo Dilma não foi a causa de ruptura, mas o clímax e pretexto de tais enfrentamentos.

Trata-se de um enfrentamento de narrativas e de memórias imaginadas e da reconstrução da atualidade de 1964, e suas ferramentas, como os Atos Institucionais, idealizados como respostas fáceis para situações complexas a partir da Crise de 2013. Para a Ultradi-

\footnotetext{
${ }^{4}$ Comissão Pastoral da Terra/CPT. Massacres no Campo. In: https://www.cptnacional.org.br/noticias/acervo/massacres-no-campo. Consultado em 22/04/2021 e Pesquisas e Práticas Psicossociais. O extermínio de jovens negros pobres no Brasil: práticas biopolíticas em questão. In: http://pepsic.bvsalud.org/scielo.php?script=sci arttext\&pid=S1809-89082017000100012, Pesquisa. prát. psicossociais vol.12 no.1 São João del-Rei jan./março 2017, consultado em 22/04/2021.
} 
reita, trata-se não só de chegar ao poder - o que conseguiu em 2018 com Bolsonaro o mas, de destruir as próprias bases da Nova República como instituídas na Constituição de 1988, apontando o Al-5 como modelo básico da "República" ideal.

\section{A República do Al-5}

O Golpe de 1964 foi original no cenário nas relações dos militares com a República no Brasil. Fugia ao "padrão" das muitas intervenções militares sob como a sucessão de "pronunciamentos", golpes, rebeliões, imposições e ultimatos que se seguiram a Proclamação da República depois de 1889. Tratou-se de uma intervenção direta, continuada, onde os militares assumiram o protagonismo político e a responsabilidade integral por uma vasta obra de legislação, arranjo político e reforma econômica, além de remodelagem institucional. A tese de que seria uma intervenção limitada - propalada por eles inicialmente -, seguida de eleições democráticas, e da entrega do poder ao eleito em 1966, não se mantém à luz dos depoimentos dos principais chefes militares. Os próprios conspiradores, em especial os coronéis "de IPMs" ${ }^{5}$, considerados radicais, liderados pelo ministro da Guerra, general Costa e Silva, tinham planos de longa duração. Liderando a chamada "Linha Dura", consideravam imperiosa a suspensão das eleições, ampliação das cassações de mandatos políticos, posto que "... a revolução teria que prosseguir com ele [Castelo Branco $^{6}$ ] no governo ou então estaria perdida e as reformas que pretendia efetuar não seriam realizadas'. O "Programa Revolucionário" que deveria mudar a face do país "...não era de molde a ser realizado em menos de dois anos", e isso os militares sabiam. Conforme está explícito no Ato Institucional, dito mais tarde "Número 1" (Al-1), embora, com alguma razão, a Ultradireita contemporânea tenha fixação no Al-5 - instrumento pelo qual o Regime Militar tornou-se ainda mais absoluto e restringiu fortemente as garantias civis -, cabia inteiramente aos militares assumir a missão de "restauração" da Nação. Para isso se auto constituíam em poder legisferante e executivo, simultaneamente, além de poder limitante do Judiciário, como expressa claramente o próprio texto introdutório do Ato Institucional Número 1 (Al-1): “A revolução vitoriosa se investe no exercício do Poder Constituinte. Este se manifesta pela eleição popular ou pela revolução. Esta é a forma mais expressiva e mais radical do Poder Constituinte. Assim, a revolução vitoriosa, como Poder Constituinte, se legitima por si mesma. Ela destitui o go-

\footnotetext{
${ }^{5}$ IPM - Inquérito Policial-Militar era uma comissão designado pelo "poder militar" para julgar subversivos, comunistas e corruptos (e atos de "imoralidade") logo após o Golpe de 1964 pretendendo uma "limpeza da Nação". Foi em especial a arma para destituir centenas de funcionários públicos da administração do Estado. Constituíram-se num grupo radical, dos "duros", que antes havia sido a base conspirativa de Golbery do Couto e Silva, tais como os coronéis, depois generais, João Baptista Figueiredo, Ivã Perdigão, Gustavo Moraes Rego, Octávio Alves Velho, Leônidas Pires Gonçalves, Newton Leitão, Daniel Venturi, Silvio Frota e Otávio Medeiros.

${ }^{6}$ Humberto Castello Branco, primeiro presidente do regime militar, 1964-1967.

${ }^{7}$ Durante o Regime Militar foram editados em seu conjunto 17 Atos Institucionais regulados por 104 Atos Complementares que compuseram o arcabouço jurídico do Estado de Exceção no Brasil, ao qual devemos acrescentar a Lei de Segurança Nacional/, de 1983, ainda vigente - em plena Nova República - embora hoje sob forte contestação.
} 
verno anterior e tem a capacidade de constituir o novo governo. Nela se contém a força normativa, inerente ao Poder Constituinte. Ela edita normas jurídicas sem que nisto seja limitada pela normatividade anterior à sua vitória. Os Chefes da revolução vitoriosa, graças à ação das Forças Armadas e ao apoio inequívoco da Nação, representam o Povo e em seu nome exercem o Poder Constituinte..." ${ }^{8}$ A vocação ditatorial do Golpe tornava-se explicita ao avocar para um grupo de militares o poder de legislar, sem qualquer limitação, inclusive do Supremo Tribunal, em nome da Nação.

O texto instaurador da nova ordem rompia, assim, a ordem constitucional e estabelecia, sem limitações de apreciação de constitucionalidade, uma nova fonte de institucionalidade e fúria punitivista. O Supremo Tribunal Federal/STF permitiu por total renúncia as suas atribuições inatas de guardião da Constituição, em especial na figura do seu, então, presidente, Ministro Ribeiro da Costa (1964-1966) o avanço do novo poder sobre suas instituições. Nesse momento, de fato, as instituições militares funcionavam como um "Quarto Poder", de forma inconstitucional, ahistórica e abusiva. A teoria da "Tutela Militar" sobre a República, oriunda da Proclamação da República e da recepção do decaído Poder Moderador do Imperador pela Instituição Militar desempenhará um papel ideológico subliminar importante em todo esse processo.

A "Linha Dura" de Costa e Silva/Silvio Frota tinham, desde logo, um projeto de longa duração, implicando na permanência na vida pública do país. Silvio Frota - mais tarde, através do seu mando no Exército e da projeção de poder no CIEx e no SNI, consolidará a dura discrepância com o Projeto Golbery-Geisel, de "Abertura". A grande diferença reside no projeto de longo prazo, ainda em vigor hoje, e não no método - variável, flexível, mutável - desde os golpes falhados de 1954, de 1961, realizado de 1964, novamente falhado em 1977 e longamente planejado desde 1988, com novos métodos, para florescer em 2016 e se realizar por via eleitoral em 2018. O Bolsonarismo enquanto síntese seria o principal condutor de um projeto de institucionalização de uma "República Patriótica Militar", sob a tutela permanente dos militares, como afirmaria premonitoriamente Silvio Frota: "...as revoluções não marcam limites no tempo. Elas, dentro da doutrina que esposaram e vêm difundir, elaboram e impõem as leis que vigorarão na nova ordem. Semeiam seus princípios, especialmente na juventude, visando a dar-lhes raízes para sustentá-la até longínquo futuro. Por conseguinte, não têm prazos e somente se exaurem com a integral concretização de seus objetivos ${ }^{9 "}$

O Al-5, decretado em 13/12/1968, seria o instrumento de perenização e aprofundamento do Golpe de 1964 - para muitos "o Golpe dentro do Golpe". Os últimos vestígios da fachada constitucional seriam abandonados e os aparelhos policiais assumiriam uma dinâmica própria, multiplicando-se os sequestros, as práticas de tortura e de exigências de "atestados de ideologia" para os mais diversos setores da vida pública. O elogio, e a ameaça de retorno, aos "tempos do Al-5, por membros da família Bolsonaro, e importantes setores do

\footnotetext{
${ }^{8}$ Ato Institucional. Preâmbulo: À Nação. In: http://www.planalto.gov.br/ccivil 03/AIT/ait-01-64.htm.

${ }^{9}$ CPDOC. Silvio Frota. Vhttp://www.fgv.br/cpdoc/acervo/dicionarios/verbete-biografico/silvio-coutocoelho-da-frota, consultado em 20/06/2020.
} 
governo, desder 2020, indicam os enlaces entre o golpismo existente durante a Quarta República, o Regime Militar e o bolsonarismo na Nova República. Um habitus que une esses mesmos grupos como uma continuidade que não foi alterada pela transição, falhada em seu intendo de democratizar o conjunto das instituições republicanas. Muito possivelmente o pacto feito pelas forças políticas em não trazer para essa arena a "questão militar", permitiu a manutenção de uma cultura autoritária e antidemocrática, capaz de construir uma antimemória, uma narrativa própria, do regime militar. Tal narrativa apresentar-se-ia como o tempo da "segurança pública", do bom uso dos bens públicos, do crescimento econômico oposto aos governos "democráticos" corruptos e ineptos. A ausência de uma severa crítica ao Regime Militar, no pós-1985, e o caráter pactuado da transição, foram exatamente as brechas que permitiram a contra narrativa antidemocrática.

\section{Civis e Militares na crise da República}

Até mesmo a extra legalidade republicana encontra seu paralelo entre as duas Repúblicas recentes na História do Brasil. Tanto na Quarta República (1946-1964), seguindo a proposta de Edgard Carone, quanto na Nova República, depois de 1988, emerge o fantasma da espionagem política, do atropelo constante da Constituição, do protagonismo de chefes militares e da refundação da ordem institucional. Golbery e seus coronéis já trabalhavam, desde o começo dos anos de 1950, na instauração de um "sistema de informações privado", paralelo ao Estado republicano, núcleo da conspiração, e que seria, mais tarde, em 1964, o embrião do SNI (figueiredo, 2018). A intenção de um "sistema de informações privado", esboçado pelo Presidente Bolsonaro e revelado por publicações jornalísticas recentes, nem mesmo é original. O IPÊS/IBAB, financiado por empresários nacionais e estrangeiros, com contabilidade própria, foi a "cortina" para a montagem desse imenso aparelho dentro do Estado, um aparelho de espionagem da cidadania, um sistema extralegal de informações: "...com milhares de fichas a respeito das principais figuras da República [...] Em 1964, já aprovado o projeto de criação do SNI, foi só transferir os arquivos da Avenida Rio Branco para a Avenida Presidente Antônio Carlos [...] onde o Serviço passou a ocupar um andar..." Na campanha eleitoral de 2018, surgiu publicamente a proposta de recriação do SNI. Na reunião ministerial de 22/04/2020 - um momento de transe das instituições republicanas - o próprio presidente da República viria a afirmar, nos moldes dos anos de 1950 e 1960, a existência de um "sistema de informações" próprio, sem o controle das Instâncias Republicanas e das mediações legais, afrontando a legalidade e revelando que os esforços de superação da ditadura e do "entulho autoritário" não foram suficientes. A reunião do gabinete presidencial de 22/04/2020, filmada e apresentada à Nação, revela uma luta intensa pelo controle das polícias, inclusive a Polícia Federal, para fins pessoais e familiares. Ao mesmo tempo, revela a existência de meandros, até então ocultos, de redes de informações não republicanas. ${ }^{10}$

\footnotetext{
${ }^{10}$ Yahoo Notícias. Um ano depois, reunião de 22 de abril ainda dá pistas para entender nossa tragédia, 22/04/2021. In: https://br.noticias.yahoo.com/um-ano-depois-reuniao-de-22-de-abril-ainda-da-pistassobre-nossa-tragedia-105724905.html, consultado em 22/04/2021.
} 
Por ironia histórica coube às lideranças conservadoras militares trazer para cena política, depois de 2014 - na contramão do "esquecimento" antes tão almejado - o debate sobre a natureza de 1964 e o alcance do Al-5. Quando os setores bolsonaristas propuseram um novo Al-5, "1964" renasceu como centro dos debates históricos. A ação dos generais Augusto Heleno e Luís Eduardo Ramos comentando o Al-5, a ausência de uma clara rejeição, e a aceitação da temática "1964" com a insistência de criar narrativas alternativas, inscrevem-se claramente na tradição, no habitus, cultivado por setores militares.

A ordem do dia do general Silvio Frota, de 1977, publicada no quotidiano "Notícias do Exército", com a preocupação de formar novos líderes no Força - "Os Tenentes de Hoje - Comandantes do Amanhã" - apontando para os ideais de 1964, mostrava-se profética. Augusto Heleno e Brilhante Ulstra serão a mimesis do próprio Silvio Frota, e por sua vez, Jair Bolsonaro e Hamilton Mourão, o serão de Brilhante Ulstra - reafirmando, cada vez mais, o futuro como imitatio do passado. Há, entre os militares, inúmeras contradições, projetos diferenciados, ciúmes e diferenças de personalidades, de geração, de armas, como apontado por Martins Filho (2021, p. 75), atestando que o vocábulo "militares" é largamente abusivo como conceito de grupo político homogêneo e, sobretudo, de unidade ideológica. Contudo, existem pontos comuns que conciliam o "núcleo duro" com o conjunto dos "moderados" que não podem ser ignorados.

O mais importante, sem dúvida, reside na contemporaneidade doutrinária dos princípios contidos na declaração "À Nação" do Preâmbulo do Al-I, de 9 de Abril de 1964. Estes são reafirmados nos manifestos publicados em defesa do bolso-fascismo enquanto síntese pelos clubes militares, em 2019/2020, e pelos "novos" coronéis. Há continuidade, reafirmação e, mesmo, orgulho e "rejuvenescimento" ideológico. Os pontos centrais de um diagnóstico da Nação em crise apontam para uma sociedade (i.) assaltada pela corrupção; (ii.) em risco frente ao conluio dos inimigos internos com o inimigo externo; (iii.) da incapacidade da elite política nacional em dirigir corretamente o Estado; (vi.) o fantasma do comunismo internacional (que pode ser aggiornato seja como getulismo, trabalhismo, brizolismo, populismo, petismo, bolivarianismo, ou qualquer outro "ismo"; e, finalmente, (vii) para as ofensas "imerecidas" às FFAA (quer dizer, a qualquer militar no governo), sempre tomando um militar em posto político como o "todo" das FFAA ${ }^{11}$. Tal habitus, marcado pelo confronto com o "inimigo interno", onde não existe adversário político, mas sim um inimigo da Nação a ser destruído, impensável em democracias consolidadas pelo fenômeno do Habituation, como propunha Rüstow, faz com que a Nova República cada vez mais se pareça com a Quarta República (1946-1964), com seu cortejo de coronéis e generais signatários de manifestos e de jantares políticos de "apoios" e de "repúdios" aos comunistas nos clubes militares.

\footnotetext{
${ }^{11}$ As semelhanças entre o "clima" ideológico da Quarta República e a Nova República é tão grande que a acusação feita pelo diretor da Funai, um militar, contra Sonia Guajajara, em abril de 2021, com base na LSN, foi de "pertencer a organizações comunistas que prejudicam o Brasil ao denegrir a imagem para o exterior (sic)" In: G1. PF intima líder indígena por documentário que critica ação do governo na pandemia. In: https://g1.globo.com/politica/noticia/2021/04/30/pf-intima-lider-indigena-por-documentario-que-criticaacao-do-governo-na-pandemia.ghtml, 30/04/2021. Consultado, 13/05/2021.
} 
A frequência de manifestos, notas e declarações - inclusive de "explicações" da Constituição - dadas por militares "juristas", na expressão agora clássica de Ulisses Guimarães -, cada vez mais aprofunda o paralelismo entre a Quarta República e a Nova República. Os Manifestos do Clube Militar, em 2020 e 2021, nada deixam a desejar aos Manifestos/Memoriais dos anos de 1950 e começo de 1960 - uns, ontem, induzidos por Golbery e demais coronéis, outros, hoje, provocados por Augusto Heleno e a Reserva bolsonarista, convergem no mesmo campo semântico de ameaças "imprevisíveis" ora contra o STF, ora contra o Parlamento, a CPI da Covid e, sempre contra, a Oposição tomada como "inimigo interno" e a eterna "ameaça comunista", mesmo quando o comunismo já não desempenha nenhum papel político.

\section{O republicanismo ferido}

A ideia de República no Brasil é bastante antiga e enraizada na história do Brasil. Antecede a Independência e foi, por quase um século, combatida pelo Coroa Portuguesa e sua sucessão, a Coroa Imperial, da Conjuração Mineira, em 1789 até as Revoltas Pernambucanas de 1817 e 1824 e as Repúblicas Proclamadas no Rio Grande e em Santa Catarina 1835-1845, e o Manifesto Republicano, de 1870, havia uma ampla agitação em prol da República no país. A proeminência da Corte do Rio de Janeiro sobre a História do País, com os grandes nomes dependentes de cargos e funções imperiais, tende a diluir o republicanismo nacional (Brito Fonseca, 2016). Mesmo nas comemorações militares nomes como Tiradentes começaram a dar lugar aos mitos como Guararapes - uma batalha da Metrópole - ou mesmo a Guerra do Paraguai, onde verdadeiramente se formou o Exército e Marinha do Brasil.

Essa mitização atinge também a Nova República. Novamente a intervenção militar apropria-se de um amplo movimento de popular. Foi um "ato interpretativo" do general Leônidas Pires Gonçalves que "interpreta" a Constituição no sentido de que José Sarney, o vice-presidente - não empossado - que seria o substituto de Tancredo Neves. De fato, a única autoridade já no cargo em linha de sucessão presidencial - Presidente do Congresso Nacional -, para substituir Tancredo Neves, era Ulisses Guimarães. Contudo, a antipatia reinante entre os militares por Ulisses, líder da oposição ao Regime Militar, emergia como uma barreira, alterando o destino da democracia no país. A passagem histórica é narrada pelo próprio Ulisses, alguns anos mais tarde, quando recorda os momentos dramáticos: "Quem assume é o Sarney!", diria Leônidas. "Imediatamente, Ulysses concorda, para surpresa do Senador Pedro Simon. (...) Ulysses [então também] retorna ao Congresso Nacional. Ali, Simon lhe pergunta por que aceitara tão rapidamente a tese de Leônidas. - O Sarney chega aqui ao lado do seu jurista. Esse jurista é o ministro do Exército. Se eu não aceito a tese do jurista, a crise estava armada" (Lago et al., 2004)

Tal precedente - os militares como intérpretes da Constituição - será recorrente na República e abrirá, em brecha, a possibilidade permanente dos militares interpretarem as leis fundamentais da República. A “ideologia da tutela” é sempre reforçada: o mito de Guararapes onde o Exército cria a Nação em 1654; a Proclamação da República; a "redenção" de 1964 e a "escolha" de José Sarney em 1985 - todos momentos decisivos em que as FFAA, quer dizer, o Exército, decidiu pela Nação, antecipou-se, tomou a si a respon- 
sabilidade de fundar, refundar, regenerar e restaurar a Nacionalidade, livrando o país com sacrifício próprio - das ameaças "solertes", invisíveis para o homem comum, mas não por isso menos perigosas, da corrupção, da subversão anarquista, comunista, socialista, bolivariana, que ameaçavam a Pátria. Tudo esse "credo" - um corpus doutrinário integral, desde a Proclamação da República, passa pelo Tenentismo, pelos "Pronunciamentos" dos anos de 1950 atravessa, a doutrina da ESG, o IPÊS/IBAB, as escolas e academias militares, até os nossos dias, povoa as mentalidades dos clubes militares e forma os novos militares - como na expressão de Silvio Frota ("dos Tenentes aos novos Comandantes"). É a estrutura da mimesis do pensamento militar brasileiro. Expressão autônoma e orgânica, autoproduzida e auto veiculada, hoje em choque com as demais instituições da República, em especial ao criar o perigoso fantasma do inimigo interno. Tal permanência, imatatio, explicita o caráter falhado da Transição, em especial em face a uma leitura especiosa do Artigo 142 da Constituição, em clara oposição ao Artigo 136, que dispõe sobre o Conselho da República e o Conselho de Defesa Nacional. Juristas de Extrema-Direita reacionária, como Modesto Carvalhosa e Yves Gandra, emergem, como parte de uma política de legitimação da tutela, ao buscar, em interpretações tortuosas, formas de prover as FFAA de uma legalidade tutorial sobre a República. A narrativa histórica é apropriada por objetivos corporativos: no lugar da épica republicana, ergue-se a história como tragédia. Em vez de Francisco Campos e Carlos Medeiros, juristas típicos do fascismo brasileiro, que prestaram seus serviços para o assassinato da brevíssima Terceira República (1934-1937) e o sacrifício da Quarta República, em 1964, os novos intérpretes do Artigo 142, buscam as brechas para a asfixia, via a própria Constituição de 1988, da Nova República. Para isso, a tropa armada é anterior à Nação e ao Povo, forjada em Guararapes, antes mesmo do Brasil existir.

\section{A Abertura "falhada", democracia falhada}

Costa e Silva e Silvio Frota - este um ativo conspirador contra a Quarta República bem representam a "Linha Dura" do Regime Militar, lutando pela permanência do "Poder Duro" e pela condução direta do Regime pelos militares no "combate à subversão e da corrupção" tinham um projeto de "República", contrário a qualquer processo de "Abertura". Não era a "República" do Projeto Golbery-Geisel e, tão pouco, a República que nasceria da pressão das ruas e da Constituinte de 1987-1988. Contudo, o "Pacto de Minas Gerais" - o encontro entre Tancredo, Sarney, Ulisses, Franco Montoro, Hélio Garcia em 14/10/1984, imortalizado em foto de Marcelo Prates no Palácio da Liberdade -, se manteria como baliza e o ministro-chefe do SNI, Ivan de Souza Mendes, cuidaria para guardar os limites da "Abertura". Em plena Transição, atuando por detrás do Governo Sarney, os generais Leônidas, no Ministério, e Ivan Souza Mendes, no SNI, serão as novas balizas do processo de "Abertura", trabalhando para evitar o "revanchismo" e garantindo a "tutela" militar de todo o processo, mediando os "avanços", e garantindo o ritmo da "Transição".

A intocabilidade das instituições militares, em especial das escolas e academias, com seu sistema educacional próprio, sua autonomia e capacidade de auto validação, seu sistema de informações e o Alto Comando - tudo protegido pelo Decreto da Anistia, de 1979 - garantindo os principais personagens do regime militar, seriam os limites da "Abertura". $\mathrm{Na}$ "Abertura" não haveria "transição militar". Os escândalos Brilhante Ulstra, em 1986, e 
Avólio, em 1995, explicitam a longa sombra do passado sobre o futuro da Nova República em virtude da recusa em reavaliar sua história. Podemos ressaltar, ainda, a própria continuidade de persona, historicamente desnecessária, porém existente, entre a "Linha Dura" de Silvio Frota, durante toda a Quarta República, como conspirador, no Regime Militar incluindo seu putsch fracassado, em 1977 contra Geisel - e a síntese extremista, na figura do atual ministro-chefe do GSI, general Augusto Heleno. A mesma sombra do passado se projeta do coronel Brilhante Ulstra reconhecidamente sobre o vice-presidente general Hamilton Mourão. Em verdade, como já foi explicitado por Martins Filho, a diversidade da "cultura militar" era, e certa forma ainda é, muito mais ampla que aquela apontada pela díade clássica de "castelistas" versus "Linha Dura".

A filiação do, então, jovem capitão Augusto Heleno ao movimento do general Silvio Frota, buscando deter, mesmo que através de um golpe de Estado, o Projeto de "Abertura" de Golbery-Geisel, em 1977, e sua atual posição predominante no bolsonarismo bem ilustra a continuidade de uma "cultura militar", um habitus, extremamente resistente ao jogo democrático e ao Império da Lei. Na verdade, a persistência de instituições retroalimentadas pelo habitus autoritário relaciona-se diretamente com as escolas/academias militares, os serviços de informações e sua ideologia de "inimigo interno" e a formação do Alto Comando do Exército/ACE. A ausência de um debate nacional sobre os anos de chumbo no qual a concórdia fosse o alvo (como na África do Sul), ou, de fato, a punição dos crimes então cometidos (como na Argentina, Grécia), ou da sua apologia (como na Espanha) criou um vácuo histórico. O bordão sempre repetido sobre "ambos os lados" desconhece que militantes de Esquerda foram julgados, tendo como base uma lei e tribunais de exceção - a Lei de Segurança Nacional - e cumpriram penas até o Decreto de Anistia em 1979.

Avançamos aqui, além da díade transições por colapso/transições negociadas, para uma outra situação histórica. Na análise de Rüstow para as diversas transições para a democracia em seguida a uma "fase de luta política prolongada e indefinida" viria uma Decision phase, na qual ambas as partes envolvidas, percebendo sua exaustão e incapacidade de se impor ao outro, decidiram-se pela aceitação do Império da Lei e do Jogo Democrático, adentrando-se na fase Habituation. O que vemos, no entanto, é a longa transição, e a própria Nova República no Brasil, sofrendo um brusco retrocesso para uma Decision Phase e um retorno, brutal, para a "luta prolongada" e de volta para a disputa de narrativas - isso entre 2013 e 2018 e mesmo 2021, incluindo a parte vencedora após chegar ao poder, em 2019, com cerca de $55 \%$ dos votos em segundo turno. Voltamos, então, a uma fase de "luta prolongada". Dá-se a ameaça constante das instituições da Nova República e, vários setores saudosistas, evocando a reedição dos Atos Institucionais do Regime Militar, apontam o passado como única forma disponível de regime para o país. Não podemos deixar de apontar que o mesmo estado de exaustão entre as forças em presença, diagnosticado por Rüstow - do qual emergiria a democracia - é apontado por Karl Marx, de forma clássica, no "18 Brumário de Luís Bonaparte", como a condição básica que permite, a autonomia de segmentos políticos e ascensão de um personagem carismático, centrado numa classe reinante, uma outra saída política: os regimes de tipo bonapartistas. 0 bonapartismo, como é classicamente descrito na literatura, é um passo para o fascismo, risco constante das democracias fragilizadas. 
O Brasil é, assim, um exemplo em movimento de transições negociadas, ou pactuadas, que chegaram, a um limite máximo da "restauração" conservadora. O que entrou em colapso foi a "Habituation" democrática antes mesmo de sua plena realização, malgrado a longuíssima "Transição". A ameaça de avanço das elites conservadoras/liberais/reacionárias (empresariado/patrimonialismo de altos funcionários, hibridismo com as classes médias, e setores militares ) se realiza, desta feita, em aliança com os setores enraivecidos das classes médias e setores populares fascistizadas, tocadas pela crise econômica e o chamado "lavajatismo" como fenômeno vingador da corrupção real e imaginária e por uma ampla massa de sub-proletários alistados pela comunicação de massas, pela "Teologia do Sucesso", o egoísmo social, o racismo e de uma versão depravada do individualismo possessivo. Tudo isso imbuído de um rude Anti-intelectualismo de caráter chulo, incentivado desde o poder. Utilizando-se das redes sociais instalou-se um ambiente em que a máxima, propalada por gurus da Extrema-Direita, de tipo "Não argumente, insulte!", impera. Em tal clima, com a utilização de fake news, robôs, e disparos automáticos, a democracia representativa é atingida em nome da tolerância. As conquistas políticas e sociais do período da transição até então consideradas asseguradas pela "Habituation", são revogadas, desde o Governo Temer (2016-2019), explicitando a condição de uma transição falhada. Em face de um habitus mais antigo e arraigado no cotidiano das instituições militares intocadas pela transição, a História permanece mimesis, uma imitatio, do já acontecido, não admitindo nenhum processo diegético - o reconhecimento do erro no passado e o pedido de desculpas. Daí a necessidade do ativismo Negacionista. A modernização das FFAA, os cursos e MBAs e similares, pós-1988, se deram na direção de formação de elites egoístas, tecnicistas, espelhadas em sociedades liberais anglo-saxãs, e distanciadas do povo e dos modernos exemplos europeus do pós-guerra, muitas das vezes com medo e desprezo, gerando a demofobia brasileira. A vivência do Haiti, por sua vez, gerou uma ideologia salvacionista, centrada mais no controle social do que na promoção social, repressiva, na qual o povo deveria ser tratado através de Operações de GLO, como inimigo interno, por vezes, a única face visível do Estado em vastas e populosas comunidades, que recuaria das ações de inclusão social para a repressão social - esse seria o principal resultado da modernização ultraliberal dos cursos ministrados pelas fundações privadas. 0 Projeto do bolsonarismo flutua numa tensão constante entre o passado e o futuro: o passado da Ditadura Militar idealizado e o futuro de uma revolução fascista. O próprio bolsonarismo é um processo em curso, não foi um acontecimento singular, acabado. O empuxo veio do entorno social, desde 2013, ou mesmo antes, com forte apoio popular, apoiado na rejeição à corrupção e perplexo perante a crise econômica, sintetizado nas faixas ubíquas de "Intervenção Militar Já" e explicitou uma, até então oculta, margem social fascista sempre presente no Brasil moderno via o integralismo, lacerdismo -, até então dormente, existente na sociedade brasileira. Neste espaço/tempo deu-se o ponto de oxidação: os sentimentos comuns exacerbados pelo lavajatismo, pela caça à corrupção, elevada, por vezes, ao grau de histeria, a crise econômica permanente e a perda de status das classes médias, com o horror da ascensão das camadas populares, tingidos, ainda, pelo egoísmo social e pelo racismo estrutural e institucional, agora recrudescidos.

O empuxo fascista, e sua charanga, é amplo, social, vem por baixo das instituições, não é militar, é societário, contudo, em simbiose com os setores duros das Forças Arma- 
das, tornou-se um risco para a democracia.

\section{Breves considerações}

"Por que não detiveram Hitler?" As primeiras gerações pós Segunda Guerra fizeram repetidamente essa pergunta aos contemporâneos de 1933 e a seus pais. As respostas nunca foram satisfatórias, sempre apontavam medo e, acima de tudo cautela. Guardada suas devidas proporções de comparação, uma parcela dos eleitores de Bolsonaro aponta cuidado ao se mostrarem hoje contrários ao governo. Mesmo com o Datafolha apontando pela primeira vez que $49 \%$ da população apoia um pedido de impeachment do presidente e $46 \%$ seriam contrários, isso não seria suficiente para demonstrar uma crise profunda no apoio e consentimento de diversos grupos as práticas políticas do governo. $O$ fato é que o apoio ao afastamento tem crescido entre jovens, especialmente entre as faixas etárias de 16 a 24 anos, desempregados e aqueles que declaram profundo medo da pandemia no novo Coronavírus. Sua base de apoio, segundo a pesquisa, ainda está ancorada no público majoritariamente masculino, do Sul do país, entre aqueles que negam a gravidade da pandemia, entre os evangélicos (neopentecostais) e grupos assalariados registrados. ${ }^{12}$ Mesmo o Brasil próximo dos 450 mil mortos na pandemia há uma base social permanente de apoio ao atual governo que coloca claramente em questão o quanto a nossa experiência democrática foi e continua inacabada. Os fatores que levaram essa democracia a ser inacabada são múltiplos e são emaranhados repletos de causas difíceis de desenredar. Não podemos deixar de considerar que nossa transição, como já explicamos nesse texto, foi "falhada", geradora dessa democracia num eterno gerúndio, inacabada. Sendo assim, nossa democracia é fruto dessa "falha" e carrega consigo as cicatrizes de um passado traumático não assumido, adormecido pela política retomada do país pós ditadura. 0 enfrentamento de um trauma coletivo carrega as responsabilidades da consequência de assumi-lo. Entretanto, sua omissão produz brechas dentro do sistema político e da sociedade que tornam os fantasmas do passado recente permanentes. Como na República de Weimar, as oposições ao sistema político vigente no Brasil produziram oposições extremas tanto na ultradireita quanto na esquerda mais radical. Esse processo de polarização, que seria mais corretamente definido como multipolarização, levando em conta que são várias direitas e esquerdas, radicalizam o discurso e rumam a um agir político autoritário capaz de construir um ambiente social favorável de destrutividade da sociabilidade, instaurador de brutalização e violência.

Möller (2012) alertou para o fato de quando as populações avançam e as instituições se paralisam, chegam as revoluções. No Brasil, por mais que as instituições que compõe a democracia sejam consideradas sólidas e até certo ponto, estáveis, sua crise de representação, nos leva a discutir o quanto as demandas sociais avançaram e já não conseguem ser atendidas por elas. Pão, renda e vacina. São as atuais motivações para retomar a ocupação das ruas, mesmo com uma brutal crise pandêmica. O Brasil vive desde 2012 sacudido por

\footnotetext{
${ }^{12}$ Ver: https://www1.folha.uol.com.br/poder/2021/05/datafolha-49-apoiam-impeachment-de-bolsonaro-e46-se-dizem-contrarios.shtml Acessado em 24/05/2021
} 
diversas crises econômicas, sociais e políticas. O impedimento jurídico da presidente Dilma Rousseff, a catastrófica gestão Michel Temer e o ambiente hostil e violento das eleições de 2018 foram sintomas fundamentais para a composição de um difícil diagnóstico de que uma parcela da nossa sociedade despertou a parte obscura, violenta e perversa que existe em cada um de nós de forma a negar princípios fundamentais da democracia. O Brasil não é e não está polarizado, porque somos extremamente heterogêneos para estar reduzidos a esse dualismo. Contudo, o que Bolsonaro tem demonstrado desde sua longa trajetória como integrante do quadro político do Congresso Nacional é que a ultradireita está integrada e normalizada dentro da arena política. As políticas da ultradireita não estão restritas a partidos políticos, muito pelo contrário, o superam e os negam, representando de fato um problema para a manutenção do sistema como ele se encontra. Por isso, a indefinição de limites torna a análise mais difícil, turva, porque a tendência comum é a separação díade entre direita e esquerda como se fosse suficiente para explicar os contornos políticos que se apresentam. Contudo, esses grupos que compõe o apoio ao atual governo do Brasil, foram por anos, décadas externalizados da política como se não existissem dentro do play. E foi justamente sua negação como ator que os transformou em atores relevantes potencializados por crises profundas de representação e autoridade legitima.

O apoio a uma direta extremada sempre foi silenciado ou mesmo ocorria sobre o mais rigoroso sigilo para não atingir a imagem pública de seus entusiastas dentro do sistema político. Com Bolsonaro, a ultradireita se trona cada vez mais normalizada dentro do sistema político e passa a integrar aquilo que outrora eles mesmo contrariavam: o maisntream. Cas Mudde (2020), pode ter razão ao afirmar que a direita extremista é uma patologia normal, enquanto a ultradireita se tornou uma normalidade patológica. Não há, nenhum país imune a ultradireita e ela veio para ficar dentro do sistema político. Nosso olhar analítico sobre o passado recente, procurando compreender os processos "falhados" de transição e a construção de democracias inacabadas podem ser a primeira forma de aprendermos a lidar com elas.

\section{Bibliografia}

Aarão Reis, Daniel (2000), Ditadura Militar, Esquerdas e Sociedade, Rio de Janeiro, Zahar.

Alves, José Claudio Souza (2020), Dos Barões Ao Extermínio Uma História Da Violência Na Baixada Fluminense, Rio de Janeiro, Consequência.

Anderson, Lisa (1999), Transitions to Democracy, Columbia, University Press.

Bachtold, Felipe (2021), «Datafolha: 49\% apoiam impeachment de Bolsonaro, e 46\% se dizem contrários», Folha de São Paulo, São Paulo. Consulta pela Internet (https://www1.folha.uol.com.br/poder/2021/05/datafolha-49-apoiamimpeachment-de-bolsonaro-e-46-se-dizem-contrarios.shtml) em 24 de maio de 2021.

Brito Fonseca, Silvia Claudia (2016), A Ideia de República no Império do Brasil: Rio de Janeiro e Pernambuco (1824-1834), Rio de Janeiro, Paco Editorial.

Castro, Celso, Exército e Nação, Rio de Janeiro, FGV. 
Costa Pinto, Antônio, (2021), O regresso das ditaduras?, Lisboa, Fundação Francisco Manuel dos Santos.

Dankwart, Rüstow (1970), Transitions to democracy: Toward a dynamic model. Comparative Politics, Vol. 2, No. 3, pp. 337-363.

Delgado, Lucília de Almeida Neves (1985), Tancredo, A Trajetória de um liberal, Petrópolis, Editora Vozes.

Dotta, Renato A. (2012), Um esboço necessário sobre a trajetória do integralismo brasileiro: da AIB ao ciberintegralismo, Boletim do Tempo Presebte (UFRJ), v. s/n, p.

Fico, Carlos (2004), Ditadura Militar, Rio de Janeiro, Record.

Figueredo, Lucas (2018), O Ministério do Silêncio, Rio de Janeiro, Record.

Frota, Silvio (2006), Ideais Traídos, Rio de Janeiro, Zahar.

Fundação Getúlio Vargas (CPDOC), "Silvio Couto Coelho da Frota», CPDOC, Rio de Janeiro. Consulta pela Internet (http://www.fgv.br/cpdoc/acervo/dicionarios/verbetebiografico/silvio-couto-coelho-da-frota) em 20 de junho de 2020.

Gandhi, Jennifer (2008), Political Institutions under Dictatorship, Cambridge, University Press. Gaspari, Elio (2014), A ditadura envergonhada, São Paulo, Editora Intrínseca.

Hanna, Wellington (2021), «PF intima líder indígena por documentário que critica ação do governo na pandemia», G1 Portal de Notícias, Rio de Janeiro. Consulta pela Internet (https://g1.globo.com/politica/noticia/2021/04/30/pf-intima-liderindigena-por-documentario-que-critica-acao-do-governo-na-pandemia.ghtml) em 13 de maio de 2021.

Huntington, Samuel (1989), In: Robert A. Pastor (Org.), Democracy in the Americas: Stopping the Pendulum, Nova York, Holmes and Holmes.

Izquierdo, Rafael Moreno (2019), «El día que "Isidoro" sedujo a los espías de Suárez», El País, Madrid. Consulta pela Internet (https://elpais.com/politica/2019/09/19/actualidad/1568907106_294742.htm l) em 20 de abril de 2021.

Lemos, Flávia Cristina Silveira et al. (2017), «O extermínio de jovens negros pobres no Brasil: práticas biopolíticas em questão», Periódicos eletrônicos em psicologia, São João del-Rei. Consulta pela Internet (http://pepsic.bvsalud.org/scielo.php?script=sci arttext\&pid=S180989082017000100012 ) em 22 de abril de 2021.

Levitskt, Steven, Way, Lucan (2010), Competitive Authoritarianism: Hybrid Regimes after the Cold War, New York, University Press.

Martins Filho, João Roberto (2020), O Palácio \& a Caserna. A dinâmica militar das crises políticas na Ditadura (1964-1969), São Paulo, Alameda.

Möller, Horst (2012), La República de Weimar. Uma democracia inacabada, Madrid, Papeles del Tiempo. 
Mudde, Cas (2020), O regresso da ultradireita. Da direita radical à direita extremista. Lisboa, Editorial Presença.

O’Donnell, Guillermo (1987), Transição Democrática e Política Sociais In: Rcv. Adm. públ., Rio de Janeiro, 21(4):9-16. out./dez.

Nolte, Ernst (1963), Der Faschismus in seiner Epoche, Frankfurt, Piper.

O’Donnell, Guillermo, Schmitter, Philippe (1991), Transitions from Authoritarian Rule. Tentative conclusions about uncertain Democracies, USA, Johns Hopkins University Press.

Paes Manso, Bruno (2018), A República das Milícias: Dos Esquadrões da Morte à Era Bolsonaro, Rio de Janeiro, Editora Todavia.

Pereira, Anthony (2010), Ditadura e Repressão, São Paulo, Paz e Terra.

Pichonelli, Matheus (2021), «Um ano depois, reunião de 22 de abril ainda dá pistas para entender nossa tragédia», Portal Yahoo Notícias, São Paulo. Consulta pela Internet (https://br.noticias.yahoo.com/um-ano-depois-reuniao-de-22-de-abrilainda-da-pistas-sobre-nossa-tragedia-105724905.html) em 22 de abril de 2021.

Presidência da República, Casa Civil, «Ato Institucional No 1, de 9 de Abril de 1964», Planalto do Brasil. Consulta pela Internet (http://www.planalto.gov.br/ccivil 03/AIT/ait-01-64.htm) em 20 de maio de 2021.

Prezeworski, Adam (2019), "Transitions to democracy" Democracy and the Market: Political and Economic Reforms in Eastern Europe and Latin America, Retrieved. Cambridge, University Press, p.-10-27.

Prezeworski, Adam (1985), Capitalismo e Social-Democracia, São Paulo, Companhia das Letras.

Py, Fábio (2020), Pandemia Cristofascista, São Paulo, Recriar.

Santa Rosa, Virgílio (1963). O que é o Tenentismo? Rio de Janeiro: Cadernos do PovoCivilização Brasileira, V.22.

Santos, Juliá (2017), Transión, Barcelona, Galáxia Gutemberg.

Stepan, Alfred (1975), Os Militares na Política, Rio de Janeiro, Arte Nova.

Weffort, Francisco (1990), Incertezas das Transições na América Latina, In: Revista Lua Nova, São Paulo, No. 16, março. 